From the Department of Reproductive Physiology and Pathology,

Norwegian College of Veterinary Medicine, Oslo

and National Veterinary Institute, Oslo, Norway.

\title{
Selenium Levels and Glutathione Peroxidase Activity in Blood, Plasma and Reproductive Organs in Dairy Cows
}

By Erik Ropstad, Arne Frøslie and Kristina Landsverk

\begin{abstract}
Ropstad, E., A. Frøslie and K. Landsverk: Selenium levels and glutathione peroxidase activity in blood, plasma and reproductive organs in dairy cows. Acta vet. scand. 1988, 29, 431-435. - Selenium levels and glutathione peroxidase activity were determined in blood and reproductive organs in 12 Norwegian dairy cows at different stages of the oestrus cycle. Blood samples were collected before slaughter, and samples from genital organs were obtained as soon as possible after slaughter. Blood and plasma selenium levels were significantly correlated with selenium levels in follicular fluid, and in ovarian and uterine tissues, but not with the levels in corpora lutea. The activity of blood glutathione peroxidase was significantly correlated with that in ovarian and uterine tissue, but not with activity in corpora lutea and follicular fluid. No effect of stage of oestrus cycle on selenium content or glutathione peroxidase in reproductive tissue was observed.
\end{abstract}

fertility; nutrition; oestrus cycle.

\section{Introduction}

The role of selenium in the reproductive process has been attributed to its function as a component of the selenium-dependent glutathione peroxidase. This enzyme is thought to interfere with the synthesis of prostaglandins and serve to maintain the integrity of membranes of importance for normal fertility (Kolb 1984).

Selenium/vitamin E deficiency in dairy cows has been reported to be associated with an increased incidence of retained placenta (Trinder et al. 1973, Harrison et al. 1984, Eger et al. 1985), delayed semen transport due to reduced uterine motility (Segerson \& Libby 1982), and decreased reproductive performance (Harrison et al. 1984). However, findings regarding the influence of selenium/vitamin $E$ on reproductive perform- ance seem to be somewhat conflicting (Gwadzdauskas et al. 1979, Kappel et al. 1984).

The purpose of this study was to evaluate blood selenium content and glutathione peroxidase activity in relation to the content and activity of these substances in the genital organs.

\section{Materials and methods}

Dairy cows of the Norwegian Red Cattle (NRF) were examined by rectal palpation of the genital organs before slaughter to determine the stage of oestrus cycle. On the basis of this examination 4 cows in pro-oestrus or oestrus, 4 cows in met-oestrus and 4 cows in di-oestrus were selected. No information was available about health performance, 
yield and feeding of the cows prior to selection.

Blood samples were collected from the jugular vein into heparinized vacutainers. The animals were slaughtered on the following day. Samples of follicular fluid from large follicles (10-20 mm diameter), corpora lutea, and uterine and ovarian tissue were collected as soon as possible after slaughter. The latter containing ovarian stroma and small $(<3 \mathrm{~mm})$ follicles. All samples were stored at $-70^{\circ} \mathrm{C}$ until analysed.

Plasma progesterone was determined as described by Benjaminsen \& Karlberg (1981). The selenium content in blood, plasma and reproductive organs was determined by a hydride generation method (Norheim \& Haugen 1986), results being expressed as $\mu \mathrm{g} / \mathrm{ml}$ or $\mu \mathrm{g} / \mathrm{g}$ wet weight. Glutathione per- oxidase activity was determined according to Paglia \& Valentine (1967), using cumen hydroperoxide as substrate, results being expressed as $\mu \mathrm{kat} / \mathrm{l}$ or $\mu \mathrm{kat} / \mathrm{g}$ wet weight.

Correlation analysis (Spearman coefficients of correlation) was used to assess the relationship between parameters.

\section{Results and discussion}

Blood selenium levels averaged $0.11 \mu \mathrm{g} / \mathrm{ml}$ (range $0.04-0.20 \mu \mathrm{g} / \mathrm{ml}$ ) indicating that selenium intake in some animals was marginal (Table 1). The great variation in blood selenium levels probably reflected differences in the feeding of concentrates prior to slaughter (Frøslie et al. 1980). The coefficient of correlation between blood and plasma selenium values $\left(r_{s}=0.93, p<0.001\right)$ was very high compared to previous findings reported by

Table 1. Mean values, standard deviations and ranges of selenium and glutathione peroxidase activity in blood, plasma and tissues from genital organs in 12 cows.

\begin{tabular}{lccccc}
\hline Tissue ${ }^{1)}$ & $\mathrm{n}$ & Mean & $\mathrm{SD}$ & $\min$ & $\max$ \\
\hline $\mathrm{Se}-\mathrm{B}, \mu \mathrm{g} / \mathrm{ml}$ & 12 & 0.11 & 0.05 & 0.04 & 0.20 \\
$\mathrm{Se}-\mathrm{P}, \mu \mathrm{g} / \mathrm{ml}$ & 12 & 0.06 & 0.03 & 0.02 & 0.10 \\
$\mathrm{Se}-\mathrm{F}, \mu \mathrm{g} / \mathrm{ml}$ & 10 & 0.05 & 0.03 & 0.02 & 0.11 \\
$\mathrm{Se}-\mathrm{CL}, \mu \mathrm{g} / \mathrm{g}$ & 11 & 0.29 & 0.10 & 0.20 & 0.56 \\
$\mathrm{Se}-\mathrm{O}, \mu \mathrm{g} / \mathrm{g}$ & 12 & 0.20 & 0.10 & 0.09 & 0.39 \\
$\mathrm{Se}-\mathrm{U}, \mu \mathrm{g} / \mathrm{g}$ & 12 & 0.11 & 0.02 & 0.06 & 0.14 \\
$\mathrm{GSH}-\mathrm{B}, \mu \mathrm{kat} / \mathrm{l}$ & 12 & 287 & 170 & 73 & 517 \\
$\mathrm{GSH}-\mathrm{F}, \mu \mathrm{kat} / \mathrm{l}$ & 10 & 3.2 & 2.5 & 1.3 & 1.9 \\
$\mathrm{GSH}-\mathrm{CL}, \mu \mathrm{kat} / \mathrm{kg}$ & 11 & 246 & 84 & 164 & 442 \\
$\mathrm{GSH}-\mathrm{O}, \mu \mathrm{kat} / \mathrm{kg}$ & 12 & 99 & 21 & 71 & 135 \\
$\mathrm{GSH}-\mathrm{U}, \mu \mathrm{kat} / \mathrm{kg}$ & 12 & 63 & 26 & 28 & 125 \\
\hline
\end{tabular}

1) Se: selenium content

GSH: activity of glutathione peroxidase
B: blood
P: plasma
U: uterus
F: follicular fluid
CL: corpus luteum
O: ovarian tissue 
Table 2. Matrix of correlation coefficients for the levels of selenium and glutathione peroxidase activity in blood, plasma and tissues from genital organs in 12 cows (Spearman correlation coefficients).

\begin{tabular}{|c|c|c|c|c|c|c|c|c|c|c|c|}
\hline \multirow[b]{2}{*}{ Tissue $^{2)}$} & \multicolumn{11}{|c|}{ Coefficients of correlation, $r_{s}{ }^{1)}$} \\
\hline & Se-B & Se-P & Se-F & $\mathrm{S}_{\mathbf{e}}-\mathrm{Cl}$ & Se-0 & $S e-0$ & GSB-B & GSH-F & GSH-CL & GSH-0 & GSH-U \\
\hline Se $-B$ & 1.00 & & & & & & & & & & \\
\hline$S_{e}-P$ & $0.93^{c}$ & 1.00 & & & & & & & & & \\
\hline$S_{e}-F$ & $0.91^{c}$ & $0.90^{\mathrm{C}}$ & 1.00 & & & & & & & & \\
\hline $\mathrm{S}_{\mathbf{e}}-\mathrm{Cl}$ & $0.23^{\mathrm{ns}}$ & $0.23^{\mathrm{ns}}$ & $0.10^{\mathrm{ns}}$ & 1.00 & & & & & & & \\
\hline $\mathrm{Se}_{\mathrm{e}}-0$ & $0.80^{\mathrm{b}}$ & $0.86^{\mathrm{C}}$ & $0.90^{c}$ & $-0.06^{\mathrm{n}}$ & 1.00 & & & & & & \\
\hline$S_{e}-0$ & $0.85^{\mathrm{c}}-$ & $0.83^{c}$ & $0.83^{\mathrm{b}}$ & $0.61^{2}$ & $0.64^{2}$ & 1.00 & & & & & \\
\hline GSH-B & $0.98^{c}$ & $0.91^{c}$ & $0.92^{c}$ & $0.32^{\mathrm{ns}}$ & $0.73^{b}$ & $0.87^{c}$ & 1.00 & & & & \\
\hline GSB-F & $0.48^{\mathrm{n}}$ & $0.37^{\mathrm{n}}$ & $0.50^{\mathrm{ns}}$ & $-0.37^{n s}$ & $0.51^{\mathrm{ns}}$ & $0.30^{\mathrm{n}}$ & $0.44^{\mathrm{n}}$ & 1.00 & & & \\
\hline GSH-CL & $c .44^{\mathrm{ns}}$ & $0.34^{\mathrm{ns}}$ & $0.18^{\mathrm{ns}}$ & $0.44^{\mathrm{ns}}$ & $-0.01^{\mathrm{ns}}$ & $0.60^{\mathrm{ns}}$ & $0.46^{\mathrm{ns}}$ & $-0.01^{n s}$ & 1.00 & & \\
\hline GSH-O & $0.68^{\circ}$ & $0.60^{\mathrm{ns}}$ & $0.72^{\mathrm{a}}$ & $0.25^{\mathrm{ns}}$ & $0.62^{2}$ & $0.57^{\mathrm{n}=}$ & $0.70^{\mathrm{a}}$ & $0.53^{\mathrm{ns}}$ & $0.46^{\mathrm{ns}}$ & 1.00 & \\
\hline GSH-U & $0.79^{b}$ & $0.82^{b}$ & $0.78^{b}$ & $0.70^{\circ}$ & $0.61^{4}$ & $0.98^{\mathrm{C}}$ & $0.79^{b}$ & $0.23^{\mathrm{n}}$ & $0.56^{\mathrm{ns}}$ & $0.48^{\mathrm{ns}}$ & 1.00 \\
\hline
\end{tabular}

1)

$$
\begin{aligned}
& c:<<0.001 \\
& \text { ns: not significant }
\end{aligned}
$$$$
\text { a: } p<0.05
$$

2) Se: selen1ua content
GSH: activity of glutathione peroxidase
B: blood
P : plasma
U: uterus
F : follicular flu1d
CL: corpus luteus
O: ovar1an t1ssue
Ropstad et al. (1987) (Table 2). This high coefficient of correlation may be explained partly by stable selenium intake for a certain period prior to blood sampling, and partly by the wideness of the range of values obtained.

The highest levels of selenium were found in corpora lutea $($ mean $=0.29 \pm 0.1 \mu \mathrm{g} / \mathrm{g}$, range: $0.20-0.56 \mu \mathrm{g} / \mathrm{g}$ ) (Table 1). The corpora lutea were at different stages of development when sampled. This may have contributed to the low coefficients of correlation found both between the levels of selenium and glutathione peroxidase in corpora lutea and other tissues (Table 2).

The levels of selenium in plasma closely reflected the values in follicular fluid (Tables 1 and 2). The activity of glutathione peroxidase in follicular fluid was close to zero, in agreement with findings reported by Harrison \& Conrad (1984), and not significantly correlated with any of the other parameters (Table 2). In contrast to Harrison et al. (1984) the coefficient of correlation between the selenium content in follicular fluid and that in blood was high $\left(r_{s}=0.91, p<\right.$ $0.001)$. This divergence is probably due to the fact that Harrison et al. examined samples which were collected after only a short period (10 days) of selenium supplementation. Short-term selenium supplementation will tend to increase selenium levels in plasma and probably also in follicular fluid, though not to the same extent the levels of selenium and also glutathione peroxidase activity in blood (Ropstad et al. 1988).

The mean level of selenium in ovaries was found to be almost twice that in blood, while 
levels of selenium in uterine tissue were quite similar to those in blood. However, levels of glutathione peroxidase in ovaries and uterine tissues were somewhat lower than might have been expected judging from selenium levels found. This may imply that glutathione peroxidase is not the only selenium-containing substance in these tissue.

The ratios between blood selenium and selenium in ovarian tissue, and between blood selenium and selenium in uterine tissue were related to progesterone value. However, due to the great variation in selenium levels as well as the limited number of animals, it was not possible to detect cyclic changes in selenium levels in the various tissues.

The results indicate that both glutathione peroxidase activity in blood and selenium levels in blood and plasma reflect the corresponding values in genital organs. Screening of blood and plasma levels can therefore be used to indirectly assess the activity and content of these substances in genital organs.

\section{References}

Benjaminsen E, Karlberg K: Post weaning oestrus and luteal function in primiparous and pluriparous sows. Res. Vet. Sci. 1981, 30, 318-322.

Eger A, Dron D, Kadvon I, Miller N, Schindler H: Effects of selenium and vitamin $\mathrm{E}$ on incidence of retained placenta. J. Dairy Sci. 1985, 68, 2119-2122.

Froslie A, Karlsen JT, Rygge J: Selenium in animal nutrition in Norway. Acta Agric. Scand. 1980, 30, 17-25.

Gwadzdauskas FC, Bibb TL, Gilliard ML, Lineweaver $J A$ : Effect of prepartum selenium-vitamin $\mathrm{E}$ injection on time for placenta to pass and on reproductive functions. J. Dairy Sci. 1979, 62, 978-981.

Harrison JH, Conrad HR: Selenium content and glutathione peroxidase activity in tissues of the dairy cow after short-term feeding. J. Dairy Sci. 1984, 67, 2464-2470.
Harrison JH, Hancock DD, Conrad HR: Vitamin $\mathrm{E}$ and selenium for reproduction of the dairy cow. J. Dairy Sci. 1984, 67, 123-132.

Kappel LC, Ingraham RH, Morgan EB, Dixon $J M$, Zeringve L, Wilson $D$, Babcock $D K, A p$ Stut $M$ : Selenium concentrations in feeds and effects of treating pregnant Holstein cows with selenium and vitamin $\mathrm{E}$ on blood selenium values and reproductive performance. Amer. J. vet. Res. 1984, 45, 691-694.

Kolb $E$ von: Neuere biochemische Erkenntnisse zur Entstehung und Verhütung der Nachgeburtsverhaltung des Rindes. (Recent biochemical findings on the cause and prevention of placental retention in cattle). Mh. Vet.-Med. 1984, 39, 325-330.

Norheim $G$, Haugen A: Precise determination of selenium in tissues using automated wet digestion and an automated hydride generator-atomic absorbtion spectroscopy system. Acta Pharm. Tox. 1986, 59, Suppl. 7, 610-612.

Paglia PE, Valentine WN: Studies on the quantitative and qualitative characterization of erythrocyte glutathione peroxidase. J. lab. clin. Med. 1967, 70, 158-169.

Ropstad E, Østerås $O$, Øvernes G, Froslie A: Seasonal variation of selenium status of Norwegian dairy cows and effects of selenium supplementation. Acta vet. scand. 1988, 29, 159-164.

Ropstad E, Øvernes G, Refsdal AO: Selenium levels in Norwegian dairy herds related to reproductive and health performance. Acta Agric. Scand. 1987, 37, 397-405.

Segerson EC, Libby DW: Ova fertilixation and sperm number per fertilized ovum for selenium and vitamin E-treated charolais cattle. Theriogenology 1982, 17, 333-341.

Trinder $N$, Hall RJ, Renton CP: The relationship between the intake of selenium and vitamin $\mathrm{E}$ on the incidence of retained placenta in dairy cows. Vet. Rec. 1973, 93, 641-644.

\section{Sammendrag}

Selennivåer og glutation peroksydaseaktivitet

$i$ blod, plasma og kjønnsorganer hos kyr. Innholdet av selen og aktiviteten av glutation peroksydase ble målt $\mathrm{i}$ blod og kjønnsorganer hos 12 kyr i forskjellige stadier av syklus. Blodprøver ble 
samlet før slakting, og prøver av vev fra genitalia ble tatt ut så snart som mulig etter slakting.

Nivåene av selen i blod og plasma var signifikant korrelert med selennivåene i follikkelvæske, ovarievev og uterusvev, men ikke med nivåene i corpora lutea. Aktiviteten av glutation peroksydase $\mathrm{i}$ blod var signifikant korrelert med nivåene av glutation peroksydase i ovarievev og uterusvev, men ikke med nivåene i corpora lutea og follikkelvæske. Det ble ikke funnet noen sammenheng mellom nivåer av selen eller glutation peroksydase og stadium i syklus.

(Received March 2, 1988).

Reprints may be requested from: Erik Ropstad, Norwegian College of Veterinary Medicine, P. O. Box 8146, Dep., N-0033 Oslo 1, Norway. 
